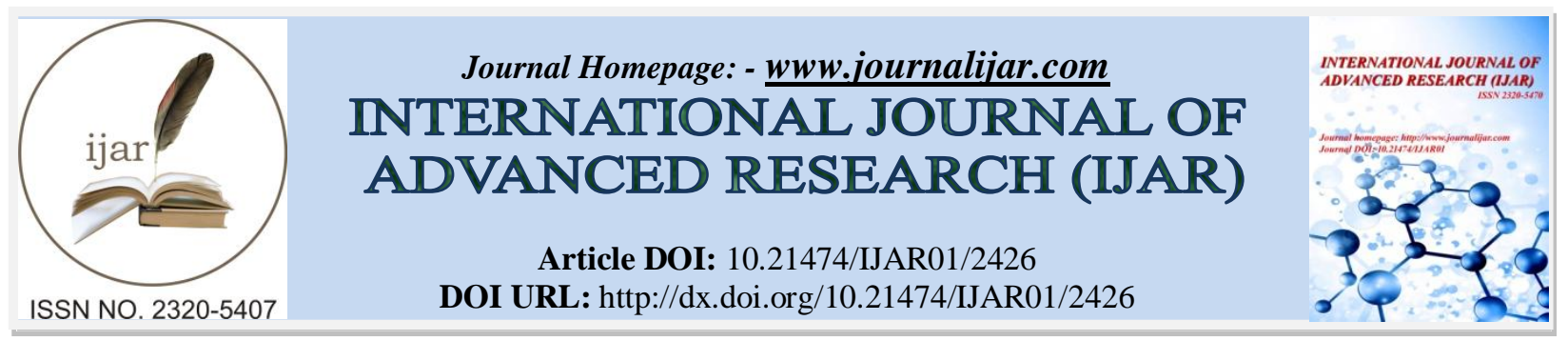

RESEARCH ARTICLE

\title{
HEAVY METALS IN BRACKISH WATER ZOOPLANKTON AT NAGORE COASTAL REGION, SOUTHEAST COAST OF TAMILNADU.
}

R. Bhuvaneswari and Serfoji. P.

Post Graduate and Research Department of Zoology, Government Arts College (Autonomous), Kumbakonam, India.

\section{Manuscript Info}

.......................

Manuscript History

Received: 20 October 2016

Final Accepted: 22 November 2016

Published: December 2016

Key words:-

Heavy metals, Zooplankton, Atomic

Absorption Spectrophotometer (AAS) and

Pollution.

\section{Abstract}

The present study was carried out to determine the heavy metal in brackish water Zooplankton of the Cauvery river basin at Nagore coastal region, Southeast coast of Tamilnadu during October 2015 to September 2016 by taking samples from Nagore Cauvery river basin and Nagore Pattanachcheri village. Zooplankton was analyzed qualiand quantitatively. The Monthly variations of physico-chemical parameters viz: temperature, salinity, $\mathrm{pH}$, dissolved oxygen and nutrients of the environment are the factors which mainly influence the production and successful propagation of planktonic life in the coastal biotopes. In this study, the heavy metals in brackish water Zooplankton such as Copper $(\mathrm{Cu})$, Zinc $(\mathrm{Zn})$, Cadmium (Cd), Mercury ( $\mathrm{Hg})$, Chromium (Cr) and Iron (Fe) were analyzed in the Sediment samples. The sample analysis was done by microwave assisted digestion and Atomic Absorption Spectrophotometer (AAS). Concentrations of heavy metals in brackish water zooplankton were corrected for metals contributed by particulate matter adhering to zooplankton organisms. The ecotoxicological importance of heavy metal uptake was apparent within the brackish water zooplankton. The presence of heavy metals in brackish water causes hazardous impact on the aquatic organisms. They are released in large concentration through effluent discharges from fiber boat industry, dry fish form issue, metal processing, paints and pigment production, biocides production, and through domestic sewage from nearby villages. The ranges of heavy metals in brackish water Zooplankton such as Copper $(\mathrm{Cu})$, Zinc ( $\mathrm{Zn})$, Cadmium (Cd), Mercury (Hg), Chromium (Cr) and Iron $(\mathrm{Fe})$ were: $5.03-42.3 ; 26.4-75.26$; 4.89-17.14; 0.012-0.112; 0.054.29 and $0.3-0.98$ and $5.67-81.26 ; 26.45-69.32 ; 5.42-8.72 ; 0.016-$ 0.163 ; $0.14-5.2$ and $0.4-0.64$ respectively. Finally, the suitability of zooplankton as an adequate biological indicator of heavy metal pollution in coastal environments is discussed.

Copy Right, IJAR, 2016,. All rights reserved.

\section{Introduction:-}

Zooplankton accumulates metals by direct absorption from brackish water and also by assimilation through food substances. Spatial studies of metal concentrations in surface zooplankton from the Indian Exclusive Economic 
Zone (EEZ) of the Nagore coastal region have revealed particularly high metal concentrations at river mouths, upwelling zones, and eddy mixing zones, in comparison to other areas. The excellent investigations dealing with heavy metal levels in plankton were documented all over the world Oceans. Heavy metals are one of the severe pollutants in natural environment due to their toxicity, persistence and bioaccumulation problems [1]. The impact of anthropogenic perturbation is most strongly felt by estuarine and brackish water environments adjacent to urban areas [2]. Pollution of the natural environment by heavy metals is a worldwide problem because these metals are persistent and most of them have toxic effects on living organisms when they exceed a certain concentration [3].

In coastal environments and brackish water, which are often characterized by large industrial settlements and urban areas, the impact of effluent discharges leads to the accumulation of heavy metals [4]. The basin of the Cauvery river basin has serious problems of organic and industrial contamination, mainly related to the disposal of tannery effluents with high content of heavy metals coming from galvanoplasties and mechanical repair shops located in the area [5]. Although the structure and composition of zooplankton of the Cauvery river basin have been studied for more than four decades, the most contaminated ecosystems of this region have not received a similar attention. In this respect, the information on the relationship between zooplankton and contamination of the Cauvery river basin, it's more important tributary in Nagore, includes some records, [6].

The brackish water ecosystems are being threatened by the discharges of untreated sewage wastes and industrial effluents. This ultimately affects the sustainability of living resources and public health. The wastes carry an enormous level of toxicants, especially the heavy metals that have the tendency to accumulate into the basic food chain and move up through the higher tropic level. Also, the wastes have negative impacts on the marine and brackish water resources which cause economic loss by affecting the migration of many aquatic creatures. As well as, anyone exposed to the waters which will cause the government to spend large amount of money to treat the polluted area [7]. Thus, zooplankton organisms may contribute to the transfer of metals to the higher trophic levels and have been chosen among other as recommended organisms in baseline studies for brackish water environment. A linkage is evident between the heavy metals in brackish water Zooplankton, aquatic system and the atmospheric mobilization and deposition of heavy metals, which has local regional and global components.

The heavy metals in mixed zooplankton organisms can generally be found in higher concentration near the coast, due to the untreated discharged of many waste products of plants close to the coast or near the rivers [8]. The average heavy metals content in zooplankton from north of Mediterranean was reported by many studies. The contamination of brackish water, due to direct exposure to atmospheric input, is probably the major source of pollution in all of the stations used in this study. The aim of the study is to bring awareness to the lack of studies concerned with the evaluation of heavy metals especially in the zooplankton and phytoplankton in this area. The phytoplankton and zooplankton are the primary and secondary producers in the food chain. This fact has not been taken into consideration in this area and other areas including countries such as India.

Zooplankton may contribute to the transfer of heavy metals to higher trophic level and have been chosen as one of the recommended groups for the baseline studies of metals in the brackish water environment. The presence of very minute quantities of pollutants may become harmful either due to their direct effect on zooplankton or indirectly due to the transfer of the pollutants to other trophic levels through zooplankton [9]. Among the heavy metals cadmium (Cd) and mercury (Hg) have the ability to accumulate in food webs, and most of the long-lived predatory species exhibits high concentration of these toxic metals [10]. Mercury pollution problems can be linked to specific sources of contamination and this is of great concern when such sources are adjacent to marine eco system supporting fisheries. The built up of metal concentration in coastal areas receiving industrial effluents and sewage may affect the growth and development of plankton leading to decrease in the productivity of the region. The uptake of metals by plankton provides an entry in to the aquatic food chain. Heavy metals are one of the constituents that affect brackish water ecosystem. Their toxicity in aquatic ecosystem determined their chemical forms.

The six most common pollutant heavy metals listed by Environmental Protection Agency (EPA) are Copper $(\mathrm{Cu})$, Zinc ( $\mathrm{Zn})$, Cadmium $(\mathrm{Cd})$, Mercury $(\mathrm{Hg})$, Chromium $(\mathrm{Cr})$ and Iron $(\mathrm{Fe})$. They are released in water bodies through effluent discharge from industries, metal processing, paints and pigment production, biocides production units and through domestic sewage. Brackish water pollution due to metals is less visible and direct as compared to other types of brackish water pollution but its effects on aquatic ecosystems and humans are very extensive. The concentration of metals varies among the fishes based on the fish species; age, developmental stage and other physiological factors. Fish accumulate substantial concentrations of mercury in their tissues and thus can represent a 
major dietary source of this element for humans. Fish are the single largest sources of mercury for man [11]. Among the heavy metals cadmium and mercury have the ability to accumulate in food webs, and most of the longlived predatory species exhibit high concentration of these toxic metals due to biomagninification.

Mohammed, [12] have observed Copper $(\mathrm{Cu})$ is an essential trace element, which is widely distributed in nature and also widely used metal industries. Copper sulphate mixed with lime is used as a fungicide. Zinc is nutritionally an essential element and is required for the activity of a number of enzymes. Above 40ppm level this metal imparts a faint but definite metallic taste and milky appearance to fresh water [13]. Cadmium [14] is distributed in earth's crust and it is principally used as the pigments in plastics and electroplating. It is also used in different industrial processes. Cadmium is toxic to plants, animals and microorganisms. The major sources of chromium emission in to the brackish water environment are the chemical manufacturing industries, cement producing plants, combustion of fossil fuel, textile industries, paper and paint industries etc. Zooplanktons being the main constituents of food of most of the fishes of the brackish water play an important role in transfer of heavy metals among the fishes through food chain. No paper has been published on the heavy metal in Zooplankton of Nagore coastal region. Hence, the present study has been undertaken to examine the heavy metals assessment $(\mathrm{Cu}, \mathrm{Zn}, \mathrm{Cd}, \mathrm{Hg}, \mathrm{Cr}$ and $\mathrm{Fe}$ ) in sediments of Nagore coastal region. Station I was Nagore Cauvary river basin and Nagore pattanachcheri village was Station II. Monthly samplings were made during forenoon from October 2015 to September 2016 for four seasons viz. monsoon (October-December), post-monsoon (January-March), summer (April-June) and pre-monsoon (July-September).

\section{Materials and Methods:-}

The study area (Figure-1) is located Cauvery river basin at Nagore Pattanachcheri village the southern part of Bay of Bengal in South East coast of Tamilnadu, India. It is extending from $10^{\circ} 30^{\prime}$ to $10^{\circ} 55^{\prime} \mathrm{N}$ latitude and $79^{\circ} 45^{\prime}$ to $79^{\circ}$ $55^{\prime}$ E longitude and medium tropical transition climate, characterized by monthly average temperature of above $27^{\circ}$ C. The relative humidity ranges from $70-77 \%$. The Nagore brackish water is situated near Nagapattinam on the east coast of India. The Nagore brackish water has its source in the Cauvery river basin of Tamil Nadu. It has a year - round connection with the sea. This river flows in to the Bay of Bengal, near Nagapattinam of Tamil Nadu. In the harbor at Nagore, there are about many hundreds of mechanized boats and catamarans, employed for fishing. In the fishing vessels they are using paints and fuels from it the waste materials are released in to the harbor area. The domestic sewages agricultural drainages and the other sewage effluents are carried out into the Bay of Bengal through the small canals and rivers.

Heavy metals in brackish water Zooplankton samples were prepared for six metals including $\mathrm{Cu}, \mathrm{Zn}, \mathrm{Cd}, \mathrm{Hg}, \mathrm{Cr}$ and Fe. Zooplankton samples were collected at monthly intervals (for a period of 12 months from October 2015 to September 2016) and were collected in precleaned and acid acid washed polypropylene bottles of one litre capacity and were immediately kept in an ice box and transported to the laboratory to avoid contamination. Heavy metals in brackish water Zooplankton samples were then filtered through a Millipore filtering unit using a Millipore filter paper (pore size $0.45 \mu \mathrm{m}$ ). The heavy metals in Zooplankton were analyzed in air-acetylene Atomic Absorption Spectrophotometer, undisturbed Zooplankton samples were collected using a grab sampler placed in plastic containers for transport to the laboratory. Sample preparation for chemical analyses involved procedures for sub sampling during drying, sieving, crushing and storage. Two identical samples of zooplankton were collected at the same time for the same period one for counting; another was preserved in a freezer after washed with same water of station. Dry weight of the zooplankton was estimated by filtering the sample through a filter paper using a vacuum pump. The filter paper was then oven - dried at $60{ }^{\circ} \mathrm{C}$ for 24 hours. The metals were determined by plasma emission spectrophotometer at Centre of Excellence, Vapi (Gujarat) India. The resulting solution was then stored in acid washed Borosil glass vials for $\mathrm{Hg}$ and polypropylene containers for other metals. Concentrations of $\mathrm{Cu}, \mathrm{Zn}$ and $\mathrm{Cd}$ in the solution were determined by aspirating the solution to a standard Flame Atomic Absorption Spectrophotometer (Perkin- Elmer model 373) and Hg was determined using a standard mercury analyzer (ECIL) by cold vapors Atomic Absorption Spectrophotometer. Blank digestions were also carried out. The mean and standard deviation was calculated. 


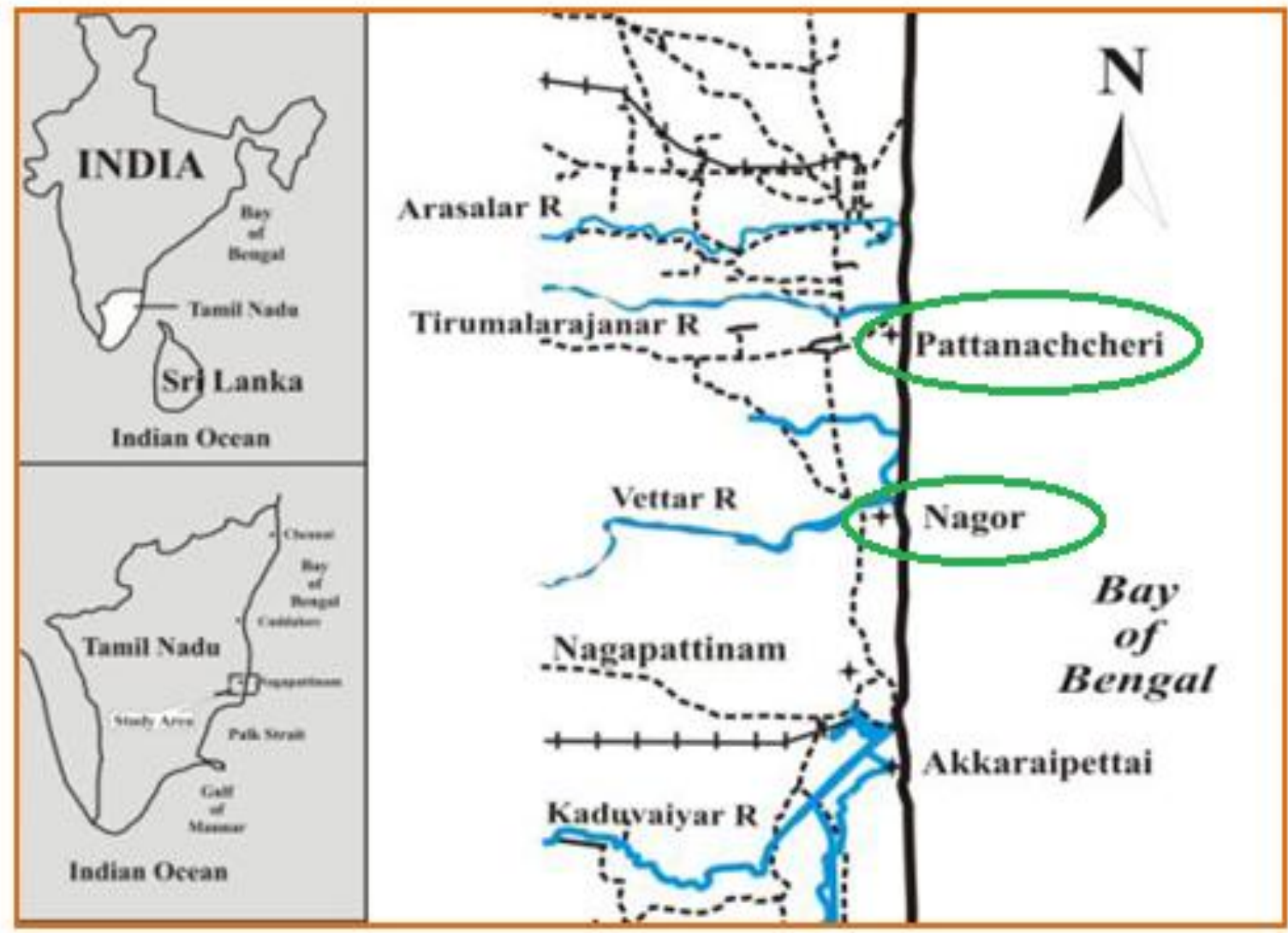

\section{Results and Discussion:-}

Figure 1:- Study area map

The physico-chemical characteristics of Nagore brackish water Zooplankton at each sampling site. The data correspond to the environmental characterization and monitoring of heavy metals in brackish water Zooplankton and sediments of the Cauvery river basin, communicated by [5]. During the study of brackish waters of Nagore experienced a warm humid climate. Among the stations, atmospheric and surface water temperature varied from $\left(0^{\circ} \mathrm{C}\right) 23-29^{\circ} \mathrm{C}$ and $24-31^{\circ} \mathrm{C}$, salinity $(\% 0) 6-35, \mathrm{pH} 7.7-8.4$, dissolved oxygen $\left(\mathrm{ml} \mathrm{l}^{-1}\right)$ were $3.07-5.66$. The values $\left(\mathrm{Cg} \mathrm{l}^{-1}\right)$ of nutrients were nitrate $(\mu \mathrm{M}) 0.84-13.5$, nitrite $(\mu \mathrm{M}) 0.07-1.89$, phosphate $(\mu \mathrm{M}) 0.06-4.58$, silicate $(\mu \mathrm{M})$ 17. 96 - 237.67 (station I \& II) respectively. The heavy metals in brackish water Zooplankton such as Copper $(\mathrm{Cu})$, Zinc $(\mathrm{Zn})$, Cadmium $(\mathrm{Cd})$, Mercury $(\mathrm{Hg})$, Chromium $(\mathrm{Cr})$ and Iron $(\mathrm{Fe})$ were analyzed in the Sediment samples. The sample analysis was done by microwave assisted digestion and Atomic Absorption Spectrophotometer (AAS). The presence of heavy metals in brackish water Zooplankton causes hazardous impact on the aquatic organisms. They are released in large concentration through effluent discharges from fiber boat industry, dry fish form issue, metal processing, paints and pigment production, biocides production, and through domestic sewage from nearby villages. Mendil and Uluozlu, [15] have reported that the sediment of heavy metals in brackish water Zooplankton such as Copper, Zinc, Cadmium, Mercury, Chromium and Iron occur in coastal region in different forms and in different concentrations. Heavy metals can enter a water supply by industrial and consumer waters or even from acidic rain, breaking down of soils and releasing heavy metals into aquatic environment [16].

The Copper concentration in zooplankton values ranged between the 5.03 to $42.3 \mu \mathrm{g} \mathrm{g}^{-1}$, with minimum and maximum concentration of $\mathrm{Cu}$ during the monsoon and post monsoon season (Stn.1) and the minimum $\mathrm{Cu}$ concentration $5.67 \mu \mathrm{g} \mathrm{g}^{-1}$ were recorded during monsoon and the maximum $81.26 \mu \mathrm{g} \mathrm{g}^{-1}$ during summer season (Stn.2). Zinc concentration in zooplankton values ranged between 26.4 and $75.26 \mu \mathrm{g} \mathrm{g}^{-1}$ with minimum and maximum concentration of $\mathrm{Zn}$ during the monsoon and summer season (Stn.1) and 26.45 to $69.32 \mu \mathrm{g} \mathrm{g}^{-1}$, with minimum and maximum concentration of $\mathrm{Zn}$ during the summer and pre monsoon season (Stn.2). Cadmium concentration in zooplankton varied from 4.89 to $17.14 \mu \mathrm{g} \mathrm{g}^{-1}$, with minimum and maximum concentration of $\mathrm{Cd}$ during the summer season (Stn.1) and 5.42 to $8.72{\mu \mathrm{g} \mathrm{g}^{-1}}$, with minimum and maximum concentration of Cd during 
the pre monsoon and summer season (Stn.2). Mercury concentration in zooplankton values ranged between 0.012 to $0.112 \mu \mathrm{g} \mathrm{g}^{-1}$ with minimum and maximum concentration of $\mathrm{Hg}$ during the monsoon and summer season (Stn.1) and 0.016 to $0.163 \mu \mathrm{g} \mathrm{g}^{-1}$, with minimum and maximum concentration of $\mathrm{Hg}$ during the pre monsoon and post monsoon season (Stn.2). Chromium concentration in zooplankton value varied from 0.05 to $4.29 \mu \mathrm{g} \mathrm{g}^{-1}$, with minimum and maximum concentration of $\mathrm{Cr}$ during the post monsoon and monsoon season (Stn.1) and 0.14 to $5.2 \mu \mathrm{g} \mathrm{g}^{-1}$, with minimum and maximum concentration of $\mathrm{Cr}$ during the pre monsoon and monsoon season (Stn.2). Iron concentration in zooplankton values ranged between 0.3 to $0.98 \mu \mathrm{g} \mathrm{g}^{-1}$, with minimum and maximum concentration of Fe during summer and monsoon season (Stn.1) and 0.4 to $0.64 \mu \mathrm{g} \mathrm{g}^{-1}$, with minimum and maximum concentration of Fe during the summer and monsoon season (Stn.2) (Table1 and 2).

Heavy Metals in brackish water zooplankton little information about spatial fluctuations of background concentrations of heavy metals in zooplankton from the Nagore brackish waters is available. To fill this gap, heavy metal concentrations in brackish waters zooplankton from the upper mixed layer (ML) of the Nagore brackish were investigated. The metal concentrations in zooplankton of the brackish water vary depending upon the sampling sites. In general, metal concentrations in brackish water zooplankton from stations in the Nagore Cauvery river basin and Nagore Pattanachcheri village. The high concentrations of heavy metals in brackish waters zooplankton collected at Nagore Cauvery river basin as well as Nagore Pattanachcheri village often coincided with high concentrations of heavy metals, and hence their higher concentrations might be attributed to their higher availability in brackish water.

Concentrations of heavy metals in brackish water zooplankton at the two stations varied seasonally. Variability in the distribution of metals appeared to be more related to hydrobiological conditions. Concentrations of heavy metals in Zooplankton especially $\mathrm{Cu}$ and $\mathrm{Zn}$ were high during the summer season. $\mathrm{Cd}$ and $\mathrm{Hg}$ concentrations in Zooplankton were high during the summer and post-monsoon season. $\mathrm{Cr}$ and Fe concentrations in Zooplankton were high during the monsoon season. Generally, the natural sources of heavy metals in coastal waters are through land and river runoff, and the mechanical and chemical weathering of rocks. The components also were washed from the atmosphere through rainfall, windblown dust, forest fire, and volcanic particles, adding to the distribution of heavy metals in water.

Low levels of $\mathrm{Cu}$ in zooplankton during the monsoon could be due to the adsorption of $\mathrm{Cu}$ on to the particulate matter and consequent settlement to the bottom. Low level of $\mathrm{Hg}$ in zooplankton might have been caused by the higher ingestion rate of organisms, resuspension of zooplankton and absorption onto the particulates during the monsoon season at this station. In both stations, the same trend of abundance of different metals was observed in the present study: the essential metal $(\mathrm{Zn})$ recording the maximum concentration and the non-essential metal (Hg) recording the minimum concentration, as observed in the Nagore coastal region along the Tamil Nadu coast. Low level of $\mathrm{Cd}$ and $\mathrm{Cr}$ in zooplankton during the pre-monsoon could be due to the adsorption of $\mathrm{Cd}$ in water at $10 \mathrm{ppm}$ level can kill fishes in one day while at 2ppm level they will be killed in 10 days. Chromium is highly toxic and responsible for several cases of poisoning through food. Low level of Fe in zooplankton during the summer due to the effects of iron is to brackish color, rusty sediment, better or metallic taste, brown green strains iron bacteria and discolored beverages. Our earlier investigations also noted the significant enrichment of heavy metals in the upper reaches of Cauvery river basin from agrochemical runoff [17].

When compared to brackish water zooplankton contained very high concentration of metals. Concentration of heavy metals in zooplankton showed at Nagore coastal region during the study period. $\mathrm{Cd}$, Fe and $\mathrm{Zn}$ concentrations were high at station I (Fig. 2) whereas $\mathrm{Cu}, \mathrm{Cr}$ and $\mathrm{Hg}$ concentrations were high at station II (Fig. 3). At both stations, $\mathrm{Cu}$ and $\mathrm{Cd}$ concentrations were high during the summer and post-monsoon season. $\mathrm{Zn}$ and $\mathrm{Hg}$ concentrations in zooplankton were high during the summer and post-monsoon. Fe and $\mathrm{Cr}$ concentrations in zooplankton were during the monsoon. The higher concentration of metals in zooplankton observed during monsoon could be attributed to the heavy rainfall and subsequent river runoff, bringing much industrial and land derived materials along with domestic, municipal, and agricultural wastes, which include residues of heavy metal containing pesticides.

$\mathrm{Zn}$ and $\mathrm{Cu}$ always have a tendency to couple with organic carbon. Decomposition of the organic matter remain are found to release heavy metals in zooplankton back to sediments and accumulated; and this process might be responsible for the strong association of $\mathrm{Zn}$ and $\mathrm{Cu}$ with organic carbon. Higher organic carbon values recorded in the post-monsoon coincided with the elevated level of $\mathrm{Zn}$ and $\mathrm{Cu}$ in zooplankton. Besides, the release of organically bound heavy metals through influx from land runoff might have also contributed elevated level of $\mathrm{Zn}$ and $\mathrm{Cu}$, 
despite they are meager in amount. $\mathrm{Zn}$ and $\mathrm{Cu}$ are generally good indicators of anthropogenic inputs. Rejomon [18] who reported that the Zinc concentration in zooplankton were high during the summer at both stations. $\mathrm{Zn}$ Concentration was low during the monsoon season at both the stations. The extensive use of antifouling paints during the peak fishing season in post monsoon would have released cuprous oxide which in turn enriches the $\mathrm{Cu}$ content in the water [19].

In summer, these metals might slightly elevate in content because the low salinity and high pH water might have caused the adsorption of these metals, leading to their removal from the water column. Significant variations observed in total heavy metal concentrations, labile fractions and lithogenic fractions could be attributed to numerous factors, such as weathering, mineral transport, anthropogenic inputs, and physicochemical components of heavy metals in zooplankton [20]. The low concentration of $\mathrm{Zn}$ and $\mathrm{Cu}$ in monsoon might be due to the prevailing lower $\mathrm{pH}$ which renders dissolved metal carbonate complexes to release free metal ions into the water column. The relative enrichment of $\mathrm{Cd}$ (at station I) and $\mathrm{Cu}$ (at station II) in the near shore metals during the post-monsoon could be attributed to the particulate fractions derived from the river runoff caused by monsoonal flow and occurrence of relatively higher percentage of particulate matter. Because Nagore brackish water is known for intensive fishing activities, the widespread use of antifouling paints in fishing boats could be a probable source of Copper [21].

Heavy metals in brackish water zooplanktons are the principal sites of $\mathrm{Hg}$ accumulation in the aquatic environment. During the pre-monsoon season, less land drainage and rainfall and less turbulence resulted in stagnant condition rather than mixing thus facilitating higher accumulation of $\mathrm{Zn}$ and $\mathrm{Hg}$ in the zooplankton. In addition, excretion and elimination of exoskeletons by abundantly occurring plankton and by settlement of particulate matter probably have played a significant role in enhancing the concentration of $\mathrm{Hg}$ and $\mathrm{Zn}$ in the zooplankton. High metal concentrations in zooplankton at station I could have been resulted from the fresh water inputs through Cauvery river basin along with land drainages. Fishing activities and anthropogenic activities might have increased the $\mathrm{Cd}$ and $\mathrm{Hg}$ levels in near shore zooplankton. Metals in zooplankton at the two stations showed a similar trend of distribution. Among the essential metals, only $\mathrm{Cu}$ and $\mathrm{Zn}$ recorded the maximum concentrations whereas the non-essential metals $\mathrm{Cd}$ and $\mathrm{Hg}$ showed the minimum concentrations.

The heavy metals are of $\mathrm{Cr}$ accumulation in the aquatic environment. Rajappa, [22] who observed that the Chromium are highly toxic and responsible for several cases of poisoning through food. Small quantities of Cd cause adverse changes in the arteries of human kidney. It replaces Zn biochemically and causes high blood pressures, kidney industrial discharge and Geological mining sites both stations show Cr concentrations high in monsoon season. A number of toxic elements are introduced into the aquatic environment from the effluents coming from the large industries resulting biodiversity and changes in water quality. For example effluents from textile mills and electroplating contained as much as 20-40ppm of chromium [13]. Exposure of man to high concentration of $\mathrm{Cr}$ may cause dermatitis, ulcer, destruction of mucus of nose and cancer of the stomachs [20]. The major source of $\mathrm{Cr}$ in water is via industrial effluents. Fe concentration was more during the monsoon season in stations due to various sources of pollution leaching of cast iron pipes in water distribution system and by natural process. Fe is found in natural fresh and groundwater, but have no health based guideline value, although high concentrations give rise to consumer complaints due to its ability to discolor aerobic waters. The pollutants that enter the inshore water and estuaries create serious problems causing extensive damage to the life and activities of the living aquatic organisms [23]. Trace element accumulation in aquatic consumers is of interest to ecologist and environmentalists so as to understand the fate and effects of contaminants in the food web dynamics as well as in the biogeochemical cycle of trace elements.

Table 1:- Mean values of heavy metals in brackish water Zooplankton of the Cauvery river basin at Nagore during the period from October 2015 to September 2016 (station I)

\begin{tabular}{|l|c|c|c|c|}
\hline \multicolumn{1}{|c|}{ HEAVY METALS } & MONSOON & POST MONSOON & SUMMER & PRE MONSOON \\
\hline Copper $\left(\mu \mathrm{g} \mathrm{g}^{-1}\right)$ & $16.08 \pm 7.36$ & $24.01 \pm 15.22$ & $19.17 \pm 4.11$ & $16.99 \pm 3.16$ \\
\hline Zinc $\left(\mu \mathrm{g} \mathrm{g}^{-1}\right)$ & $42.59 \pm 11.99$ & $57.15 \pm 7.81$ & $54.27 \pm 19.23$ & $53.76 \pm 18.66$ \\
\hline Cadmium $\left(\mu \mathrm{g} \mathrm{g}^{-1}\right)$ & $8.6 \pm 0.66$ & $8.13 \pm 1.48$ & $10.33 \pm 5.09$ & $7.12 \pm 1.81$ \\
\hline Mercury $\left(\mu \mathrm{g} \mathrm{g}^{-1}\right)$ & $0.02 \pm 0.01$ & $0.05 \pm 0.02$ & $0.068 \pm 0.03$ & $0.045 \pm 0.008$ \\
\hline Chromium $\left(\mu \mathrm{g} \mathrm{g}^{-1}\right)$ & $3.52 \pm 0.86$ & $0.68 \pm 0.45$ & $1.88 \pm 0.73$ & $1.49 \pm 0.95$ \\
\hline Iron $\left(\mu \mathrm{g} \mathrm{g}^{-1}\right)$ & $0.71 \pm 0.20$ & $0.54 \pm 0.09$ & $0.30 \pm 0.15$ & $0.24 \pm 0.06$ \\
\hline
\end{tabular}


Table 2:- Mean values of heavy metals in brackish water Zooplankton of the in Pattanachcheri village at Nagore during the period from October 2015 to September 2016 (Station II)

\begin{tabular}{|l|c|c|c|c|}
\hline \multicolumn{1}{|c|}{ HEAVY METALS } & MONSOON & POST MONSOON & SUMMER & PRE MONSOON \\
\hline Copper $\left(\mu \mathrm{g} \mathrm{g}^{-1}\right)$ & $13.19 \pm 5.68$ & $26.27 \pm 19.90$ & $54.22 \pm 27.89$ & $26.08 \pm 1.32$ \\
\hline Zinc $\left(\mu \mathrm{g} \mathrm{g}^{-1}\right)$ & $41.36 \pm 5.88$ & $52.22 \pm 7.69$ & $46.09 \pm 15.11$ & $48.80 \pm 16.62$ \\
\hline Cadmium $\left(\mu \mathrm{g} \mathrm{g}^{-1}\right)$ & $7.58 \pm 0.79$ & $7.28 \pm 1.01$ & $7.42 \pm 0.91$ & $6.42 \pm 0.99$ \\
\hline Mercury $\left(\mu \mathrm{g} \mathrm{g}^{-1}\right)$ & $0.05 \pm 0.013$ & $0.11 \pm 0.06$ & $0.059 \pm 0.02$ & $0.02 \pm 0.01$ \\
\hline Chromium $\left(\mu \mathrm{g} \mathrm{g}^{-1}\right)$ & $3.56 \pm 1.27$ & $1.40 \pm 0.33$ & $1.79 \pm 0.26$ & $1.42 \pm 0.90$ \\
\hline Iron $\left(\mu \mathrm{g} \mathrm{g}^{-1}\right)$ & $0.49 \pm 0.14$ & $0.34 \pm 0.05$ & $0.4 \pm 0.24$ & $0.17 \pm 0.01$ \\
\hline
\end{tabular}

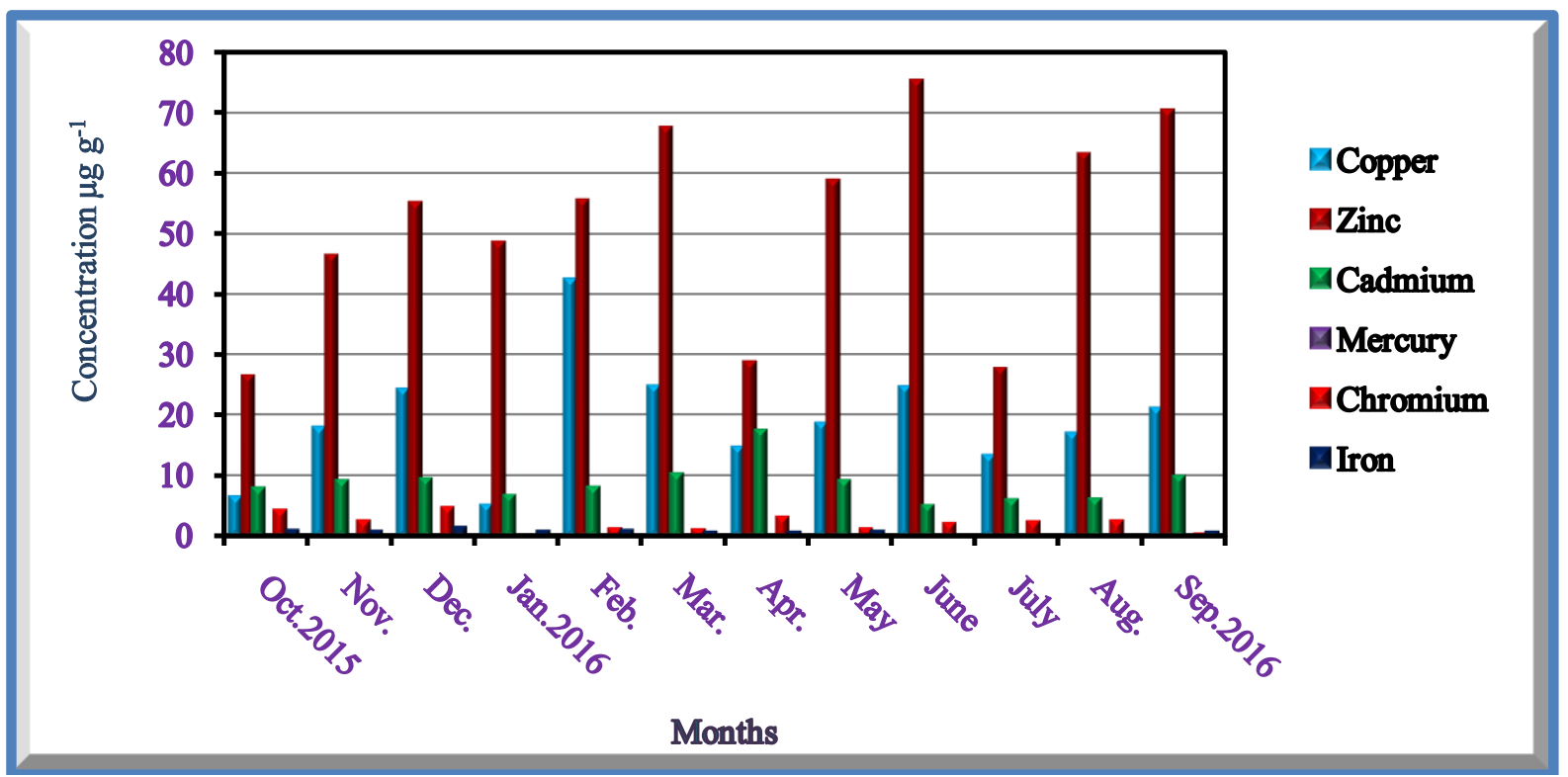

Fig 2:- Showing high concentration of heavy metals in brackish water zooplankton for each month at Nagore Cauvary river basin (Station I).

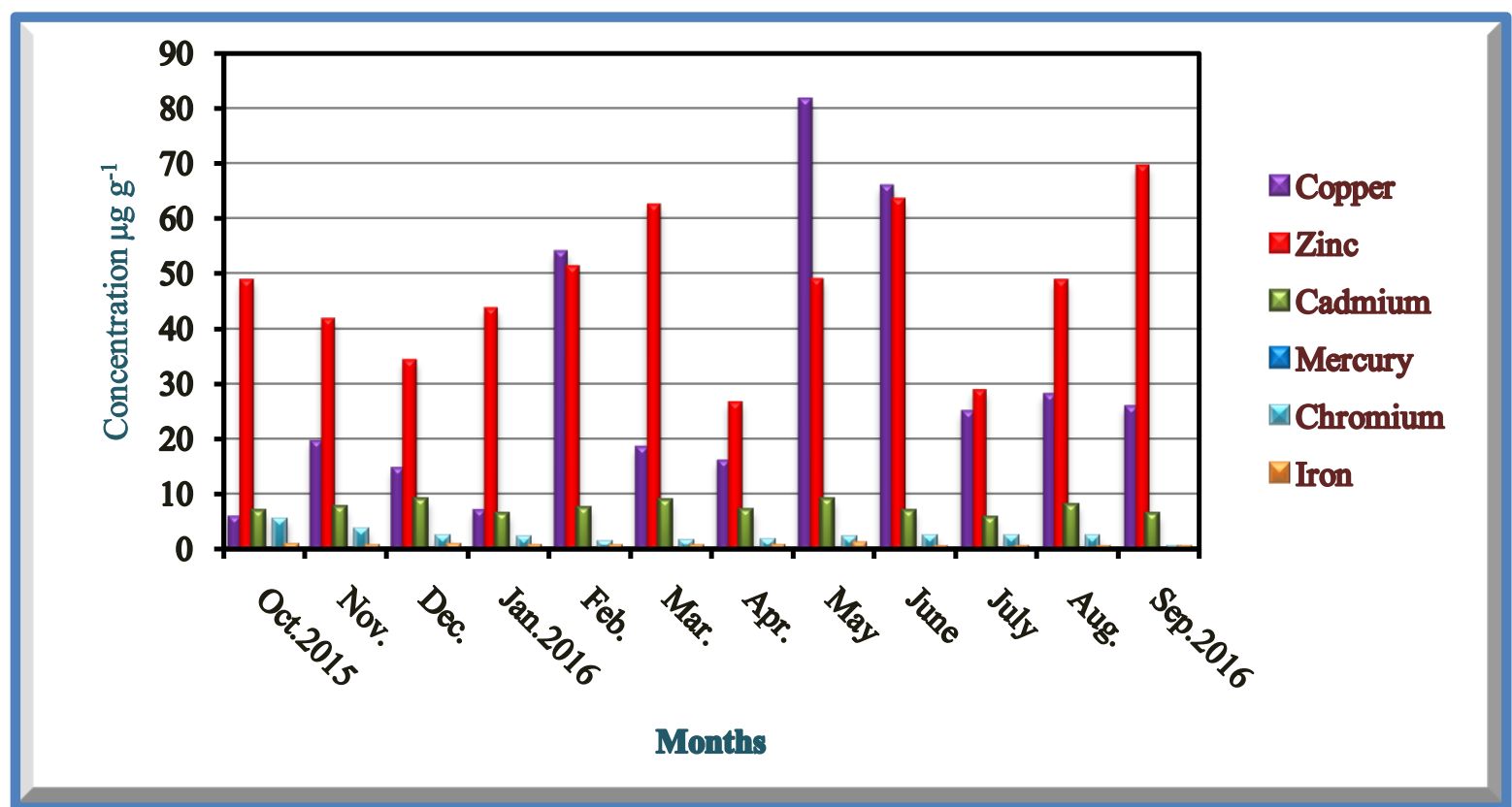

Fig 3:- Showing high concentration of heavy metals in brackish water zooplankton for each month at Nagore pattanachcheri village (Station II). 


\section{Conclusion:-}

The heavy metals in brackish water zooplankton such as $\mathrm{Cu}, \mathrm{Zn}, \mathrm{Cd}, \mathrm{Hg}, \mathrm{Cr}$ and $\mathrm{Fe}$ were dangerously higher than the maximum contaminant levels (MCL) recommended for unpolluted or drinking water. Heavy metals in zooplankton of the Cauvery river basin and Pattanachcheri village show its association with various geochemical forms. Relatively higher enrichment of heavy metals in zooplankton of brackish water samples compared to the offshore was attributed to be the river discharges carrying substantial industrial effluents which in turn could increase the bioavailabilities thereby uptake of metals. Cauvery river basin is a good example of a site where contributions of pollutants both from natural (lithogenic) sources and anthropogenic activities. The major sources of pollution of the Nagore Cauvery river basin are the industrial effluents, return flows, agricultural runoff, municipal and domestic sewage besides pedogenic background contributions. During the study period, the sediment samples during monsoon season showed significantly lower values than pre-monsoon, post-monsoon and summer season samples. The main reason behind the lower concentration during the Monsoon season is the dilution factor with the pollutant. Metals accumulation by zooplankton is mainly by two pathways such as direct uptake from water, the assimilation from injected food and detritus. The water body surrounding Nagore coastal region is contaminated with heavy metals especially $\mathrm{Zn}, \mathrm{Cr}, \mathrm{Cu}$ and $\mathrm{Cd}$ which can contaminate sea foods and hence humans. Fishing activities and anthropogenic activities might have increased the $\mathrm{Cd}$ and $\mathrm{Hg}$ levels in near shore sediments. Fe is found in natural fresh and groundwater, but have no health-based guideline value, although high concentrations give rise to consumer complaints due to its ability to discolor aerobic waters. The high level of Iron in this study could be attributed to their industrial sources carried through rivers discharges which increases the Bioavailabilities thereby uptake of metals by zooplankton. Zooplankton is very important in the cycling processes of elements in the coastal water since it is a secondary producer in the food chain. Moreover, being a major source of food for larger animals, their role in transporting the metals to the higher tropic level. Heavy metals parts and effluents from industrial and commercial activities such as fishing (nets, hooks, etc) shipping, timber processing and outboard engine boats influenced the levels of metals along the Nagore Pattanachcheri village while domestic activities (such as building materials, solid wastes). The area is contaminated with heavy metals and requires creation of awareness, periodic monitoring and evaluation of sea foods since most communities along the aquatic depend on sea foods and use the water for salt production after crystallization. Therefore the water was highly contaminated and polluted with heavy metals and not recommended as a drinking water for human consumption. These regimes are determined by hydrographic processes like upwelling, cyclonic eddies and warm gyres, and future studies should focus on metal concentrations in phytoplankton and the primary food web of the Nagore coastal region. Nevertheless, and looking for a global evaluation of the studied ecosystems, the addition of complementary information (i.e., heavy metal concentrations in brackish water zooplankton suspended particulate matter and other organisms like fishes, mollusks, etc.) is recommended. The findings of the study indicate the need for proper industrial planning and the safe disposal of industrial and urban waste. Otherwise high levels of pollutants in to brackish water ecosystem of Nagore and would greatly invite socioeconomic disaster.

\section{References:-}

1. Pekey, H., 2006, the distribution and sources of heavy metals in Izmit Bay surface sediments affected by a polluted stream. Marine Pollution Bulletin, 52 (10), 1197 - 1208.

2. Nouri, J., Karbassi, A.R., and Mirkia, S., 2008, Environ mental management of coastal regions in the Caspian Sea. International Journal of Environmental Science and Technology, 5 (1), 43 -52

3. Chakraborty, R., Zaman, S., Mukhopadhyay, N., Banerjee, K., and Mitra, A., 2009, Seasonal variation of Zn, $\mathrm{Cu}$ and $\mathrm{Pb}$ in the estuarine stretch of west Bengal. Indian Journal of Marine Science, 38 (1), $104-109$

4. Ridgway, J., and Shimmield, G., 2002, Estuaries as reposito-ries of historical contamination and their impact on shelf areas. Estuarine, Coastal and Shelf Science, 55, 903-928.

5. Gagneten, A. M., Gervasio, S., and Paggi, J. C. (2007). Heavy metal pollution and eutrophication in the Lower Salado River Basin (Argentina). Water, Air, and Soil Pollution, 178, 335-349. DOI: 10.1007/s11270-006-92022.

6. Gagneten, A. M., \& Ceresoli, N. (2004). Efectos del efluente de curtiembre sobre la abundancia y riqueza de especies del zooplancton en el Arroyo Las Prusianas (Santa Fe, Argentina). Interciencia, 29(12), 702-708.

7. Robin, R.S.; Mudulli, P.R. Vishmu Vardhan, K.. Ganguly, D. Abhilassh, K.R. and Balasubramanian, T. (2012). Heavy metal contamination and risk assessmentin the marine environment of Arabian sea, along the southwest coast of India, Amr. J of Chem. 2(4): $191-208$.

8. Rezai, H. and Yusoff, F.M. (2011). Heavy metals in neuston from the straits of Malacca, J. of Persian Gulf Mar. scie. pp 1-10. 
9. Rezai,H., Yusoff, F.M. and Yap, C.K., 2003.Murcury in zooplankton from the Malacca Straits. Indian Journal of Marine Sciences, Vol. 32(3):240-243 pp.

10. Bocher, P., Caurant,F., Miramand,P., Cherel,Y. and Bustamante,P., 2003. Influence of the diet on the bioaccumulation of heavy metals in zooplankton - eating petrels at Kerguelen archipelago, Southern Indian Ocean. Polal Biol., Vol. 26 :759-767.

11. Khayatzadeh J., Abbasi E., 2010. The Effects of Heavy Metals on Aquatic Animals, The 1 st International Applied Geological Congress, Department of Geology, Islamic Azad University - Mashad Branch, Iran, 688694.

12. Mohammed, A.A. 2009. Accumulation of Heavy Metals in Tilapia Fish (Oreochromis niloticus) from ALKhadoud Spring, AL-Hassa, Saudi Arabia. American Journal of Applied Science 6 (12): 2024-2029.

13. Asthana and Meera Asthana. (2005). Environment problems and solutions in pollution of Earth' surface : Land and water 3. Non-Degradable pollutants fifth edition, S. Chand and Company, New Delhi, pp 166-181.

14. Dara, S.S. (2004). Environmental Chemistry and Pollution control in Trace elements - Pollution and Control $7^{\text {th }}$ edition. S.Chand and Company, New Delhi, pp 177-216.

15. Mendil, D and Uluozlu, O.D. (2007). Determination of trace metals in sediment and five species from lakes in Tokat, Turkey. Food Chemistry, 101, 7396-745.

16. Nayar. S. K. (2006). Tree canopies. Air pollution and plants. A state of the art Report. Ministry of Environment and Forests, New Delhi, India.

17. Dhanakumar S, Mani U, Murthy RC, Veeramani M, Mohanraj R (2011) Heavy metals and their fractionation profile in surface sediments of upper reaches in the Cauvery river delta, India. Int J Geol Earth Environ Sci $1: 38-47$.

18. Rejomon G., Nair M., Joseph, T, (2010) Trace metal dynamics in fishes from the southwest coast of India. Environment Monitoring and Assessment, Doi: 10.1007/s 10661-009-1046-Y.

19. Ananthan, G., P. Sampathkumar, C. Palpandi and L. Kannan (2006): Distribution of heavy metals in Vellar estuary, Southeast coast of India. J. Ecotoxicol. Environ. Monit., 16, 185-191.

20. Sundaray SK, Nayak BB, Lin S, Bhatta D (2011): Geochemical speciation and risk assessment of heavy metals in the river estuarine sediments a case study, Mahanadi Basin India. J Hazard Mater 186:1837-1846.

21. Karthikeyan, R., S. Vijayalakshmi and T. Balasubramanian (2007): Monthly variations of heavy metals and metal resistant bacteria from the Uppanar estuary (Southeast coast of India). Res. J. Microbiol., 2, 50-57.

22. Rajappa, B., Manjappa, S and E.T. Puttaiah, (2010). Monitoring of heavy metal concentration in groundwater of Kakinaka Taluk, India. Contemporary Engineering Sciences, 3(4):183-190.

23. P. Martin Devaprakash and T.Hidayatulla Khan (2008). "Impact of Tsunami on the heavy metal accumulation in water, sediment and fish at Poompuhar coast, southeast coast of India". E .Journal of Chemistry 5(1) 16-22. 